\title{
TALES OF CITIES: CITY BRANDING THROUGH STORYTELLING
}

\author{
*Halit KESKIN \\ **Ali Ekber AKGUN \\ *Cemal ZEHIR \\ **Hayat AYAR \\ *Y1ldı Technical University \\ **Gebze Technical University
}

\begin{abstract}
As an intriguing concept, storytelling has attracted many researchers from a variety of disciplines. However, a specific context of storytelling approach, city branding through storytelling has rarely been reported in the literature. In this study, we show how cities can regard storytelling as a strategic branding tool and investigate how authorities and marketers can create the core story of a city's brand. This study contributes to the literature in three ways. First, the theoretical framework proposed highlights the role of storytelling both as a strategic branding concept, and as an operational communication tool in the city brand building process. Second, based on the Laboratory model of Fog et. al. (2005) we propose a strong basic framework for city brand through; scanning basic internal and external information, distilling basic information, formulating core story and the ACID test. Third, this research integrates storytelling literature to the city marketing literature through offering a basis framework where the process of generating the city's core story consists of four elements (message, conflict, cognitive and affective components and plot) leaning on the critical principles of storytelling.
\end{abstract}

Keywords: Storytelling, Branding, City Branding, Core Story, Tales of Cities.

\section{INTRODUCTION}

City branding, which is viewed as a strategic instrument that promotes a city's competitive advantages, becomes a broad practice to market the city's history, quality of place, natural and cultural resources, social opportunities and attractions, lifestyle, and nature for opportunity, prestige or power in capital formation in a dynamic market (Zhang and Zhao, 2009). However, intensified competition among cities, which involves universal changes of preferences, resources, capital, and people, presents challenges for cities' branding efforts (Kirgiz, 2013). In this respect, researchers in a variety of disciplines have emphasized the storytelling approach as an effective and influential technique to breathe new life into brands and to drive market changes (Fog, Budtz and Yakaboylu, 2005, Aaker and Smith, 2011).

However, it should be noted that while the storytelling approach is often invoked in the marketing literature, it has received little attention in the travel and tourism marketing context. Even though the destination marketing literature has mentioned the role of storytelling on destination image formation (Ramkissoon, Nunko and Gursoy, 2009), travel intentions (Akgün, Keskin, Ayar and Erdoğan, 2015), and destination development (Mossberg, Therkelsen, Huijbens, Björk and Olsson, 2010), the storytelling approach has usually appeared as a useful tool to create successful brand both on a corporate and on a product level. But, a city can also launch its products or services in a better and profitable way, attract people, visitors, enterprisers, activities, and take an active role in the world events, just like a company. In this sense, a city needs to adopt the appropriate strategies in order to brand itself successfully, as Merrilees Miller and Herington (2013) emphasized. Therefore, storytelling should be regarded as an influential and valuable technique in the city's brand building process.

City branding has been approached from both brand/city marketer and consumer/visitor viewpoints. From former viewpoints, city branding is "the self-conscious application of branding to places as an instrument of urban planning and management" (Kavaratzis and Ashworth, 2005: 507). Here, it is emphasized that city branding is a process and an applied marketing discipline, based on marketing and communications activities. Its end-product is a city brand. As an example of the latter, Baker (2007) defines city branding as the sum of all beliefs, ideas and impressions that people associate with a place. Here city branding is a combination of cognitive and emotional assessments, which makes the selection unique. In a city's brand 
building process, storytelling has the power to strengthen the city both internally (producer perspective) and externally (consumer perspective). The difference lies in the story, because the story is what drives the bond between the producer and the consumer (Fog, et. al., 2005).

In this respect, by integrating Fog et. al. (2005) and Aaker and Smith (2011) studies, this study propose that storytelling can be employed both as a city branding concept and as a city communication tool and has both a strategic and an operational dimension. The interplay between those two dimensions is the starting point for cities in their work with storytelling in the branding process.

\section{BACKGROUND}

\section{Storytelling}

Since the seminal studies of Pellowski (1990) on the "nature of storytelling" and Aaker and Smith (2011) on the "power of storytelling", the term "storytelling", which is defined as "sharing and combining of knowledge and experiences through narrative and anecdotes in order to communicate complex ideas, concepts, and causal connections and build connections and associations", is given a great deal of attention in a variety of disciplines, such as sociology (Polletta, Chen, Gardner and Motes, 2011), psychology (Wyer, 1995), management (Boje, 1991; McKee, 2003), and marketing (Pera, Viglia and Furlan, 2016; Makkonen, Aarikka-Stenroos and Olkkonen, 2012). Organizational studies have indicated its potential in areas such as cultivating norms and values (Buckler and Zien, 1996), building trust and commitment (Wilkins, 1984), communicating tacit knowledge (Wijetunge, 2012), facilitating unlearning (Sole and Wilson, 2002), generating emotional connection (Denning, 2002), managing organizational change (Abbey, 2010), and promoting entrepreneurial efforts (Garut et al. 2014). Specifically, marketing researchers have noted that while traditional advertising investigates storytelling as a sales promotional tool to generate recognition and identification (e.g. Duracell 'Trust Your Power' Commercial Campaign), modern advertising experts view it both as a driving force of strategic branding and as an operational communication tool (e.g. Nike's "take it to the next level” campaign) (Aaker and Smith, 2011). Additionally, they have asserted that, as a concept, storytelling has gained a determinant foothold in the dispute on how brands of the future will be formed (e.g. Volkswagen's “Think Small” campaign) (Fog, et. al. 2005).

In addition to the definitions and features of storytelling in these product-level and organization-level studies, we observe that storytelling can be a more appropriate way to enhance co-creation of social, emotional and epistemic values that are part of a tourist's value domain (see Mathisen, 2013). For instance, Mossberg et. al. (2010), in their destination and stories studies, noted that stories can make up constituent parts of destination marketing and development; the researchers then developed a theoretical model which shows that storytelling is a multi-actor, multi-level process leading to destination development. Martin and Woodside (2011) argued that storytelling blogs provide creative clues for positioning a destination uniquely and meaningfully in the minds and hearts of potential future visitors. More specifically, from a heuristic perspective, Kuo-Lun, His Peng and Wan-Chin (2013) and Akgün et. al. (2015) empirically illustrated the impact of the elements of storytelling blogs (i.e perceived aesthetics, narrative structure, and self-reference) on readers' intention (i.e. visit and recommend intention) through empathy and attitude.

Although, based on the above studies and theories, we observe that the literature on storytelling and destination marketing is emerging or growing, a theoretical and empirical investigation of storytelling in a special type of destination marketing (i.e. city branding) remains missing in the literature. Therefore, to enhance the storytelling theory in city branding, we argue that when a city's tangible and intangible attributes are showed as a list of bullet points in the Tourism Reports or in a brochure, they become anonymous and irrelevant, talking to the mind but not to the heart. Here, we specifically suggest that when the city tell a story, those attributes come to life through powerful images and place the city's values in a more dynamic context; this is consistent with Fog et. al.'s (2005) conceptualizing of StoryLab, developing the company core story.

\section{City Branding}

Students of organization and marketing theory indicate that branding is part of the vision, culture, and image alignment (Hatch and Schultz, 2001), interaction with multiple stakeholders (Jones, 2005), interdepartmental coordination (Hankinson, 2007), brand-centered HRM practices (Martin, Beaumont, 
Doig and Pate, 2005) and permeate the brand communication (Braun, Kavaratzis and Zenker, 2010), consumer evaluations (Chan, Peters and Marafa, 2015), consumer intentions (Dragolea and Cotirlea, 2012), brand leadership (Noni, Orsi and Zanderighi, 2014), and brand extensions (Keller and Aaker, 1998), as the organizations have the corporate and product brands (see, Fog, Budtz and Yakaboylu, 2005). Indeed, organizations use a number of basic brand strategies to build recognition and strong personal relationships with customers. For instance, Lego and Unilever present opposite poles of the spectrum. Lego's brand is corporate brand that exists independently of the individual products, but, these products e.g. Lego Architecture, also support the overall Lego corporate brand (Inspire and develop the builders of tomorrow); the gist of what makes Lego, Lego. A range of strong product brands like Lipton and Domestos on the other hand, drives Unilever. These product brands appear separately within their own obviously described identities, while corporate Unilever stands silently in the background. For such these companies, the strategic focal point is to generate powerful core stories for each of its product brands in such a manner that they don't disagreement with each other, or with the corporate brand.

Additionally, with fascinating cities such as New York, Rio de Janeiro, Istanbul and London allocating valuable resources towards branding (Braun, 2012), travel and tourism marketer and destination planners have paid increasing attention to the branding concept (Hultman, Yeobah-Banin and Formaniuk, 2016; Merrilees, Miller and Herington, 2013; Chan, Peters and Marafa, 2015). Along with this trend is increased scholarly interest to what researchers identify as city branding. Although some researchers declare that cities are not products that are used for commercial activities in marketplaces (Peterson, 1981), city branding researchers (e.g. Russell, Mort and Hume, 2009; Kavaratzis and Ashworth, 2005; Parkerson and Saunders, 2005) propose that the term product branding should actually be adapted to city branding. They mention that a city's cognitive (e.g. natural and cultural resources, atmosphere, social setting and environment etc.) and affective components (e.g. pleasant, exciting etc.) should be regarded as an "asset" (Kavaratzis, 2004). Just as a product, a city can produce useful functions that target audiences can experience through daily commercial activities and related actions. Cities can be seen as spatially extended products and cities can rival with each other in a manner that is similar to rivalry between products. For this reason, cities should be considered as "products" to be marketed, through destination development and through branding activity. In this context, researchers have addressed a wide variety of issues, including city brand image and personality (Hosany, Ekinci and Uysal, 2006), residents' brand attitudes (Merrilees et al., 2009), branding implications for fascinating cities (Merrilees et. al., 2013) and frameworks for effective city branding (Kavaratzis, 2004).

For successful city branding efforts, Kavaratzis (2004) suggests that it should be answered the six key questions. The questions involve "(1) what the city definitely is; (2) what the city perceives it is; (3) what the city tells it is; (4) what the city is considered to be; (5) whom the city aims to serve; and (6) what is offered and anticipated?”. On that basis, he shows that city branding can be interpreted within a 3-stage interaction model. The first stage expresses the tangible and visible sides from which a city can be observed. The second stage comprises promotion tools that a city introduces and adopts to market itself. Finally, it is people's communication about a city through their voices (word and mouth, recommend) and social media (blogs, social networks). In the implementation of city branding, this multi-stage interaction model construct a utility pyramid, which composes of different levels of utility, including the tangible utilities to both residents and foreign people and the development of the city's reputation which comprises added value.

Nevertheless, it should be noted that even though it is known that a clear city brand helps people to understand a city's character, there is still a conspicuous lack of critical insight as to how city branding can make a difference. Therefore, destination marketer or city planner should begin developing a positive and powerful core story for their city brand. 


\section{City Branding Through Storytelling}

Based on Fog et. al.’s (2005) Laboratory model, this study aims to assess how cities can consider storytelling as a strategic branding tool and to investigate how city marketer can create the core story of their city brand. Figure 1 illustrates the process of generating the city's core story. In this sense, we treat every level of the process in depth.

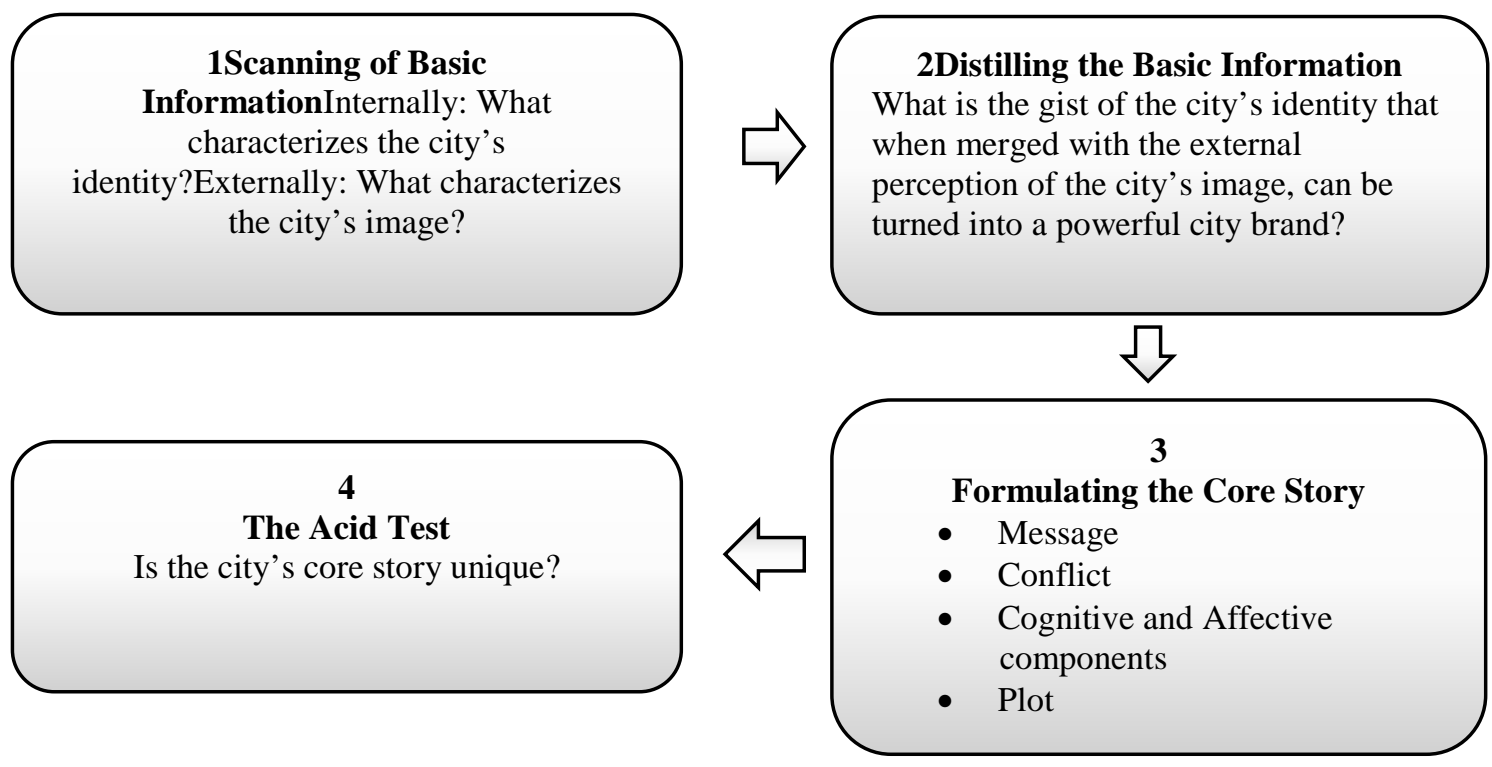

Figure 1. Developing the city's core story

\section{Scanning of Basic Information}

The primary strategy for city branding is the creation of a positive and strong city identity, which should be developed from the unique set of attributes and values such as historical, physical, socio-cultural, demographic, economic and political characteristics (Zhang and Zhao, 2009). Here, city authorities must acquire a robust understanding, at large, of its circumstance and how it is perceived, both internally and externally (Fog, et. al., 2005). While they have their own ambitions and are liable for the building process of city branding (e.g. Mayor of London launched the Smart London Plan), people share their experience with the city on varied means and in varied shapes, acting as "brand ambassadors" to reflect the city. People generally turn their perceptions (emotions, assessments and impressions) into their own comprehensible identity of the city. City branding should embody both the aspiration of authorities and the experience of people. If the city's identity and core values are discordant with what can be experienced by people, there is a major risk that city branding would compose of rather supreme values that are not acknowledged by the community (Zhang and Zhao, 2009). Thus, city planners can build a coherent image of city brand that reflects the internal and external perceptions, experiences, impressions.

\section{Internal Basic Information}

In order to define the city's attributes and values, city planners need to explore what makes it tick internally, which in turn, ensures the basis for the city's core story. Figure 2 shows the essential principles of this process: 


\section{City's vision, mission and values}

What is the city mission and what is the vision behind it? What values does the city presume to be most fundamental and why? How do these values show themselves in real city life? How are they shared internally and externally?

\section{Key milestones in city's history}

How can residents factually define the city's historical process? Which have been the city's most significant events? What anecdotes about famous and influential people and facts are yet being narrated within city?

\section{Residents' stories}

What do residents say about the city? Which stories do they narrate about the city? Which events and experiences do residents use to represent the city? What is it that makes the city a distinguished place to live and visit? Where do residents sense that the city makes a special?

\section{Figure 2. Scanning the Internal Information}

\section{External Basic Information}

The aim for scanning external basic information is to map the city's position and prestige at the international level and to clarify strengths, weaknesses, opportunities and threats of the city. However, its principal aim is to explore what kind of image the city has in the hearts and minds of visitors. Here the following areas are relevant:

\section{Global Tourism And Travel Trends}

How do current global tourism and travel trends show themselves? What do they mean in terms of where the city is positioned now?

\section{Travel opinion leaders}

Which individuals or organizations are opinion leaders in travel decision making and trip planning process? What do travel agencies and social media (travel blogs and websites) say about the city? What do they think about the attractions, atmosphere, infrastructure and value of city?

\section{Visitors}

What stories are repetitive visitors telling about the city? What do residents in other cities say about the city? How is the city positioned compared to other cities at the international level? Who are the target visitors and what are decisive motives for their decisions to visit the city?

\section{Partners}

What are the city's marketing partners that have an active role in supporting and advising on strategies and practical issues? What projects have been solved together with those partners? What do these projects mean about the city's values?

\section{Distilling the Basic Information}

When the internal and external information sources have been scanned, city and destination marketers are faced with a pile of information that has to be handled. Herein, they need to cut to the quick and focus on the gist of what makes the city special (Fog, et. al. 2005).

The aim of the core story is to reconcile the city's identity with the external sense of the city. This is the building block of a positive and powerful brand. Here, it is needed to recognize the nature of a probable 
gap between the city's identity and its community image. In other words, it is critical to describe the contrasts and harmonies between internal and external information. For example, while the city of London aims to position itself as a smart city in which people want to live, work and play, foreign visitors perceive it as unfriendly, expensive and dirty (TripAdvisor' report, 2012). In this case, by distilling internal and external basic information, marketers can determine fields that should be emphasized in future communication in order to act the city's identity and image together.

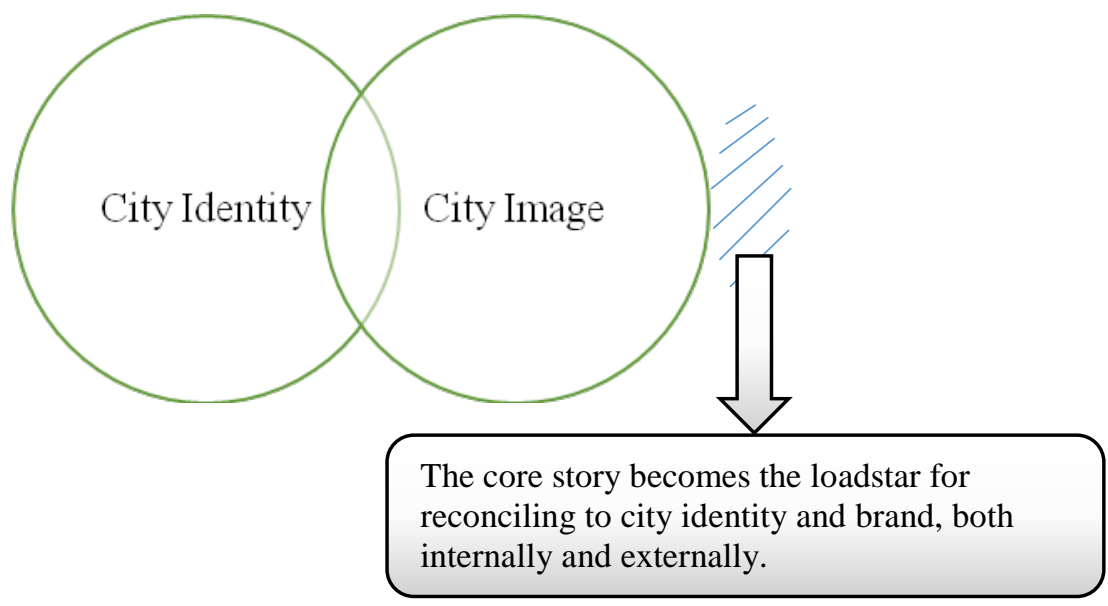

Figure 4. Closing the Gap

\section{Formulating the Core Story}

\section{Message}

The message should not be confused with a slogan. A slogan is a short and attractive statement that contains the message generally launched in city advertising. For instance, "The City That Never Sleeps" is New York's slogan, however its message is that the city have the potential to realize people's dream regardless of sex, age or creed. A single focused message should provide direction, motivation and operational guidance. In this regard, the message comprises five design principles (Figure 5) (Aaker and Smith, 2011).

\section{HUMANISTIC}

Focus on understanding people rather than making assumptions about quick solutions

\section{ACTIONABLE}

Use the attributes and values of city to attract people's attention.

\section{TESTABLE}

Identify a gap between the city identity and the city image

\section{CLARITY}

Get personal, unexpected and visual Make a visceral connection

Happiness

Ensure that city message is meaningful to residents and your

Figure 5. Components of a Good Message 


\section{Conflict}

When city planners have verified on a possible preceding message for city's core story, the next stage is to appraise the level of conflict within this message. Because conflict produces the dynamics of a good story. Through conflict, the city can make its stand while expressing its core values at the same time (Fog, et. al. 2011). Branding literature suggests that a conflict is not essentially a negative, rather the catalyst for generating a special brand since it is simple to express what companies do not reflect, instead of attempting to express what they do (Kavaratzis, 2004).Without conflict, therefore, it is considerably hard to establish and sustain a powerful core story. To reinforce its brand, for instance, "Zaragoza city concluded to employ a sole slogan for all its target groups: "a challenge, a city". This aggressive slogan emphasizes that "if you have a challenge, Zaragoza is the city for you, and that the city is united by the way it welcomes a challenge”. The essence behind this slogan is that it improves the image and values of the Zaragoza city brand. This original tagline satisfies two requirements: it brings residents together in a broad aim and it allures enterprises and investment to Zaragoza” (Daclin, 2010).

\section{Cognitive and Affective Components}

Looking across various definitions and perspectives, a common theme emerged from the tourism marketing literature, which is that the relative position of a destination determine through a comparison of cognitive attributes and affective impressions (Baloglu \& MaCleary, 1999). Specifically mega-events, which has features of indelibility, permanent interest, memorable experience, and professionalism of organization, may have an influential effect in both converting and branding a city (e.g Milan fashion week, Cannes Film Festival, Johannesburg safari tour...). Utilizing the chance to host such events is viewed as a great chance to announce focused messages about the city and its attractions to numerous people in the city's target audience (Zhang and Zhao, 2009). "When Oslo hosted the 2010 Eurovision Song Contest, NRK (the host broadcaster) combined the local tourist office VisitOSLO into the organization. Thus, by generating the best working environment for artists, the press and Eurovision members, the event produced a tremendous amount of positive and wide media coverage all over the world, promoting Oslo's image as a city of paradoxes in culture and nature” (Daclin, 2010).

\section{The Plot}

Because a city's core story is a strategic platform for communication, it should be launched in a way that is widely acceptable, easily marketable, presentable and open to experience in a daily manner (Fog, et. al. 2005; Zhang and Zhao, 2009). In other words, city branding has to be related to how culture and history, economic development and socio-cultural advance, infrastructure and architecture, atmosphere, landscape and natural environment, can be synthesized into a vendible identity that is admissible to all people (Zhang and Zhao, 2009). For instance, Verona conveys a really special charm especially to lovers so that they can feel and imagine the real story behind the literary work, almost as if Romeo and Juliet had really existed. The city of Florence is also known as the cradle of the Renaissance for its monuments, churches, and buildings.

\section{ACID Test}

The Acid Test investigates whether the city's core story is original regarding other cities. The branding can be viewed as a success if it is able to present core city values that are deemed coherent, distinguishing, attractive, enduring, and expressible (Kotler and Gertner, 2002). Because a lot of cities have similar features to deliver, a strategy of city branding is to produce original values, so differentiating one city from another. By catching the atmosphere of the city and its features, branding permits a city to indicate its unique strengths, to share an explicit message, and to charm enterprisers, organizations, visitors and pop-culture activities at both a national and international level. For example, "Karlstad has generated a brand and logo from its classic image (quality of life) in Sweden: The lodestars of this message are a charming, progressive city; a focus on people to assure a city for everybody and a green and sustainable city. Since 1989, its logo has been a smiling sun, underlining its sunny position and disposition. In this way, Karlstad's branding strategy distinguishes it from other cities” (Daclin, 2010).

\section{DISCUSSION AND IMPLICATIONS}

This study contributes to a theoretical understanding of the success factors about using storytelling to brand a city and how city marketer and planner ascertain and generate the city's core story. By 
highlighting the role of the core story in branding efforts of a city, this research ensures a framework for marketing researchers and practitioners to envisage and comprehend how cities can consider storytelling as a strategic branding concept and marketer can establish a powerful, sustained brand through holistic (both as a branding and communication tool) storytelling, thus enhancing the movement of the storytelling-based approach in the city branding literature.

This study demonstrated the theoretical relationship of storytelling marketing with branding concept. Especially based on Fog et. al.'s (2005) Laboratory model which explains the process of generating the company's branding story we showed four crucial principles of storytelling (scanning basic information, distilling basic information, formulating core story and The ACID test) in the city branding process. This proposed model enhances previous studies (Hsiao, et. al. 2013, Merrilees et. al. 2013) in the literature by specifically exploring the influence of storytelling on city branding. In this respect, for a successful city branding, this model suggests that core story must 1) reflect both city identity and city image, 2) recognize and reconcile the contrasts and harmonies between the city's identity and its community image, 3 ) include four elements (message, conflict, cognitive and affective components and plot) that compose the core value of storytelling, and 4) confirm whether the city's core story is original.

The proposed model also contribute to the research of city marketing by providing in-depth understanding of the important elements for generating the core story of a city. In addition, the importance of storytelling as a branding and communication tool was verified. Storytelling was found to build emotional link between a city or corporate and their target groups and can be viewed as a building block of branding process in the research of marketing or branding. The results are consistent with previous findings (e.g. Aaker and Smith, 2011) which indicate that storytelling is a quick, effective, and powerful way to direct people's interest.

\section{CONCLUSION AND FUTURE RESEARCH}

This study explores the key components of a city's core story and investigates how these components influence the city's branding process. The proposed model raises understanding of the influence of a city's core story on their target groups (residents, foreign visitors, investors). Our study suggest that scanning basic internal and external information, distilling basic information, formulating core story and The ACID test are the key principles of a core story and these elements influence the heart and mind of the city's target group to build a clear and original city brand. From a practical viewpoint, insights provided by the study can help city marketer and planner and tourism organizations and institutions manage their projects to attract more visitor and investor.

Moreover, the concept of storytelling triggers the opportunity for future research. First, since storytelling literature misses the empirical examination of the relationship between the core story's components and city branding in particular, the proposed model warrants an empirical and experimental investigation. Second, this research only showed the role of storytelling in tourism marketing context. The role of a core story can be explored in the future in different context. 


\section{REFERENCES}

Aaker, J., and Smith, A. (2010), The Dragonfly Effect, First Edition, Jossey-Bass.

Abbey, G.P. (2010), Making sense of organizational change: a storytelling approach. Thesis (Doctor of Philosophy (PhD)). University of Bath.

Akgün, A.E., Keskin, H., Ayar H. and Erdogan, E. (2015), The Influence of storytelling Approach in Travel Writings on Readers' Empathy and Travel Intentions, 11th International Strategic Management Conference, Procedia - Social and Behavioral Sciences (207), pp.577 - 586.

Baker, B. (2007), Destination Branding for Small Cities: The Essentials for Successful Place Branding, Creative Leap Books, Oregon. http://books.google.com/books?id=hl3Mx-

k31_sC\&pg=PA1\&dq=Destination+ Branding+for+Small+Cities\#v=onepage\&q=\&f=false

Baloglu, S. and McCleary, K.W. (1999), A Model of Destination Image Formation, Annals of Tourism Research, 26(4), pp. 868-897.

Boje, D. (1991), The Storytelling Organization: A Study of Story Performance in an Office- Supply Firm, Administrative Science Quarterly, 36(1), pp.106-126.

Braun, E., Kavaratzis, M., Zenker, S. (2010), My City - My Brand: The Role of Residents in Place Branding, Paper presented at the 50th European Regional Science Association Congress, Jönköping, Sweden.

Buckler, S.A. and Zien, K.A. (1996), The Spirituality of Innovation: Learning from Stories, Journal of Product Innovation Management, 13(5), pp. 391-405.

Chan, C.S., Peters, M. and Marafa, L.M. (2015), Public Parks in City Branding: Perceptions of Visitors Vis-À-Vis Residents in Hong Kong, Urban Forestry \& Urban Greening, 14(4), pp.1157-1165.

Daclin, J.M. (2010), A Shared vision on City Branding In Europe, Retrieved from http://www.eurocities.eu/eurocities/documents/A-Shared-Vision-on-City-Branding-in-Europe-WSPO8PLFNF

Denning, S. (2002), The Narrative Lens: Storytelling in 21st Century Organizations, Knowledge Directions, 3(2), pp. 92-101.

Dragolea, L.L. and Cotirlea, D.A. (2012), One Step Closer TO City Branding Through Culture: Consumer Preferences for Cultural Tourısm Services in Alba Iulıa - Customization on National Museum of Unıfication, Annales Universitatis Apulensis : Series Oeconomica, 14(2), pp.680-687.

Fog, K., Budtz, C. and Yakaboylu, B. (2005), Storytelling: Branding in Practice. First edition, SpringerVerlag Berlin Heidelberg.

Garud, R. Schildt, H.A. and Lant, T. (2014), Entrepreneurial Storytellıng, Future Expectatıons, and the Paradox of Legitımacy, Organization Science, 25(5), pp. 1479-1492.

Hankinson, G. (2007), The Management of Destination Brands: Five Guiding Principles based on Recent Developments in Corporate Branding Theory, Journal of Brand Management, 14(3), pp.240-254.

Hatch, M.J. and Schultz, M. (2001), Are the Strategic Stars Aligned for Your Corporate Brand. Harvard Business Review, 79(2), pp.128-134.

Hosany, A., Ekinci, Y. and Uysal, M. (2006), Destination Image And Destination Personality: An Application of Branding Theories to Tourism Places, Journal of Business Research, 59(5), pp. 638-642.

Hsiao, K-L., Lu, H-P. and Lan, W-C. (2013), The Influence of the Components of Storytelling Blogs on Readers’ Travel Intentions, Internet Research, 23(2), pp.160-182.

Hultman, M., Yeboah-Banin, A.A:, Formaniuk, L. (2016), Demand and Supply Side Perspectives of City Branding: A Qualitative Investigation, Journal of Business Research, Retrieved from http://ac.elscdn.com/S0148296316302594/1-s2.0-S0148296316302594-main.pdf?_tid=3d196290-2bd5-11e6-b0c000000aab0f6b\&acdnat=1465210733_1b08fbaeacda72e376fec8a26517cbf8 
Jones, R. (2005), Finding Sources of Brand Value: Developing a Stakeholder Model of Brand Equity, The Journal of Brand Management, 13(1), pp.10-32.

Kavaratzis, M. (2004). From City Marketing to City Branding: Towards a Theoretical Framework for Developing City Brands, Place Branding, 1(1), pp.58-73

Kavaratzis, M. and Ashworth, G.J. (2005), City Branding: An Effective Assertion of Identity or a Transitory Marketing Trick?, Tijdschrift Voor Economische En Sociale Geografie, 96(5), pp. 506-514.

Keller, K. L. and Aaker, D.A. (1998), Corporate-Level Marketing: The Impact Of Credibility on a Company’s Brand Extensions. Corp. Reputation Rev. 1(August) pp. 356-378.

Kırgiz, A.C. (2013), City Branding Based on Marketing Aesthetics. LAP LAMBERT Academic Publishing.

Kotler, P. and Gertner, D. (2002), Country as Brand, Product, and Beyond: A Place Marketing and Brand Management Perspective, Journal of Brand Management, 9(4), pp.249-261

Makkonen, H., Aarikka-Stenroos, L. and Olkkonen, R. (2012), Narrative Approach in Business Network Process Research-Implications for Theory and Methodology, Industrial Marketing Management, 41(2), pp. 287-299.

Martin, G., Beaumont, P., Doig, R. and Pate, J. (2005), Branding: A New Performance Discourse for HR?, European Management Journal, 23(1), pp.76-88.

Mathisen, L. (2014), Storytelling and Story Staging. Co-Creating Value in Tourism, A dissertation for the degree of Philosophiae Doctor UiT The Arctic University of Norway. Retrieved from http://munin.uit.no/bitstream/handle/10037/6153/thesis.pdf?sequence=9\&isAllowed=y

McKee, R. (2003), Storytelling that moves people. A Conversation with Screenwriting Coach Robert McKee, Harvard Business Review, 81(6):51-5, pp.136.

Merrilees, B., Miller, D. and Herington, C. (2009), Antecedents of Residents' City Brand Attitudes, Journal of Business Research, 62(3), pp. 362-367.

Mossberg, L., Therkelsen, A., Huijbens, E., Björk, P. and Olsson, A. K. (2010), Storytelling and Destination Development, Nordic Innovation Centre (NICe) Project. Retrieved from http://www.nordicinnovation.org/Global/_Publications/Reports/2010/201012_StorytellingAndDestination Development_report.pdf

Noni, I.D., Orsi, L. and Zanderighi, L. (2014), Attributes of Milan Influencing City Brand Attractiveness, Journal of Destination Marketing \& Management, 3(4), pp. 218-226.

Parkerson, B. and Saunders, J. (2005), City Branding: Can Goods and Services Branding Models be Used to Brand Cities, Place Branding, 1(3), pp.242-264

Pera, R., Viglia, G. and Furlan, R. (2016), Who Am I? How Compelling Self-storytelling Builds Digital Personal Reputation, Journal of Interactive Marketing, 35, pp. 44-55.

Polletta, F., Chen, P., Gardner, B. G., and Motes, A. (2011).,The Sociology of Storytelling, Annual Review of Sociology, 37, pp.109-130.

Ramkissoon, H., Nunkoo, R. and Gursoy, D. (2009), How Consumption Values Affect Destination İmage Formation, in Arch G. Woodside, Carol M. Megehee, Alfred Ogle (ed.) Perspectives on Cross-Cultural, Ethnographic, Brand Image, Storytelling, Unconscious Needs, and Hospitality Guest Research (Advances in Culture, Tourism and Hospitality Research, Volume 3) Emerald Group Publishing Limited, pp.143168.

Russell, D., Mort, G.S. and Hume, M. (2009), Analysis of Management Narrative to Understand Social Marketing Strategy: The Case of 'Branding Logan City’, Australasian Marketing Journal, 17(4), pp. 232237.

Sole, D., and Wilson, D. (2002), Storytelling in Organizations: The Power and Traps of Using Stories to Share Knowledge in Organizations, LILA, Harvard, Graduate School of Education. 
TripAdvisor Report (2012), We're unfriendly, expensive and dirty: what tourists REALLY think of London, according to TripAdvisor retrieved from http://www.standard.co.uk/news/london/wereunfriendly-expensive-and-dirty-what-tourists-really-think-of-london-according-to-tripadvisor8412183.html

Wijetunge, P. (2012), Organizational Storytelling as a Method of Tacit-Knowledge Transfer: Case Study from a Sri Lankan University, The International Information \& Library Review, 44(4), pp. 212-223.

Wilkins, A. (1984), The Creation of Company Cultures: The Role of Stories and Human Resource Systems, Human Resource Management, 23(1), pp.41-60.

Wyer, R. S. (1995), Knowledge and Memory: the Real Story, Lawrence Erlbaum Associates, Hillsdale, New Jersey.

Zhang, L. and Zhao, A.X. (2009), City Branding and the Olympic Effect: A Case Study of Beijing, Cities 26, 245-254. 